\title{
Žáner nehistorický román
}

\section{Genre of a Non-Historical Novel}

\author{
Viera Žemberová \\ (Prešov, Slovensko)
}

\section{Abstrakt:}

Ruský autor Jevgenij Vodolazkin sa profesijne venuje literárnohistorickému výskumu stredovekej ruskej literatúry a kultúry. Ide o výnimočné dejinné a duchovné obdobie známe pod názvom Stará Rus. Ruský stredovek v jeho spoločenských črtách zvýrazňuje dobe zodpovedajúca forme štátneho útvaru a ním utváraný systém politickej, ekonomickej a vojenskej moci a rozvinutost' humánneho vedomie obyvatel'stva. Stará Rus je krajina uzavretá a zaostávajúca svojou vzdelanost’ou, vyspelostou, právnym vedomím za západnými čast’ami kontinentu, má nerozvinutú sociálnu a kultúrnu štruktúru v prevažujúcom vidieckom spôsobe života. Ten sa sústreduje na poznávanie, na mravnú a tradovanú normu života, ktorú určuje a ovláda dobové krest’anské duchovenstvo. Laurus ponúka príbeh ludského života, od ranej mladosti ide o sirotu Arsenija, mladého muža a liečitela bez rodiny s novým menom Ustin, po zložení slubu už o mnícha Ambróza až po smrt’ toho istého muža vo veku svätca pomenovaného Laurus. Autor na premene mien tej istej postavy ilustruje jedinečnost' stredoveku, ktorý poskytol za dobových okolností premeny a zmeny všetkého neživého aj živého, aby sa všetko a všetci vytratili do času a z pamäti potomkov.

\section{Klúčové slová:}

žáner; román; literárny čas; literárny priestor; rozprávač; postava; meno postavy; cesta; kláštor; historické informácie; ahistorická fikcia 


\section{Abstract:}

Genre of a non-historical novel. Russian author Yevgeny Vodolazkin is professionally engaged in literary-historical research of medieval Russian literature and culture. This is an exceptional historical and spiritual period known as the Old Russian. The Middle Ages of Russia, in its social features, accentuate the time corresponding to the form of the state and the system of political, economic, and military power and the development of the human consciousness of the population. Old Russia is a closed country and lagging behind with its education, maturity, legal consciousness beyond the western parts of the continent, it has an undeveloped social and cultural structure in the prevailing rural way of life. It focuses on cognition, the moral and traditional norm of life, which is determined and controlled by contemporary Christian clergy. Laurus offers a story of human life, from the early age of an orphan Arsenija, a young man of a healer without a family named Ustin, to the promise of the monk Ambrose, to the death of the same man, the age of the saint named Laurus. In transforming the names of the same figure, the author illustrates the uniqueness of the Middle Ages, which in good circumstances provided the transformations and changes of all inanimate and alive so that everything and everyone would disappear into time and memory of the offspring.

\section{Key words:}

genre; novel; literary time; literary space; narrator; character; character name; path; monastery; historical information; ahistoric fiction

\section{Prolegomena}

Do miléniového kultúrneho a literárneho života vstupuje ruský prozaik Jevgenij Vodolazkin svojím, v ruskom literárnom prostredí najúspešnejším románom Laurus z roku 2012, ktorý slovenský vydavatel opatril týmto vyznačením, „Laurus je neobyčajná kniha o neobyčajnom svete a neobyčajných ludoch v ňom“" Prozaik

1 Jevgenij Vodolazkin (1964, Kyjev) pracuje v Oddelení staršej ruskej literatúry v Inštitúte ruskej literatúry Ruskej akadémie vied, je známy pod názvom Puškinov dom. Popri literárnohistorickom výskume ruskej stredovekej literatúry a kultúry je J. Vodolazkin úspešný autor v ruštine vydaných románov Soloviov a Larionov (2009), Lavr (2012), Aviator (2015) a Brisbane (2018). Prozaik získal v roku 2019 literárnu Cenu Alexandra Solženicyna za literárnu tvorbu a nomináciu na Cenu Andreja Belého za román Soloviov a Larionov v roku 2005, ako aj cenu Bolšaja kniga za najlepšiu prózu roka v ruštine; Cenu Arkadija a Borisa Strugackých a opät’ výročnú cenu Bolšaja kniga v roku 2015 za román Aviator (Letec). 
Vodolazkin pripojil k názvu románu Laurus spresňujúcu a do podtitulu vloženú genologickú a žánrovú informáciu - „nehistorický román“. Na tomto pozadí žánrovej typológie a oslovenia o trojnásobnej neobyčajnosti románu prirodzene vzniká, popri paradoxe formy a iniciácie na zdôvodnenie prítomnosti gradovaného vymedzenia z neobyčajností (taký by vlastne mal byt každý literárny artefakt aj ambícia autora, aby jestvovala príčina zverejnit jeho text pre čitatelov), závažný podnet na uvažovanie, aké sú kvalita, prečo a či skutočne sú poetologické danosti románu Laurus - byt’ neobyčajný - obsiahnuté v žánrovej, strategickej, poetologickej, tematickej opozícii vyjadrenej $\mathrm{v}$ typológii historický román a nehistorický román / prozaický text. Žánrová problematika historickej prózy má svoje výskumom podporené dávne aj hlboké zázemie $\mathrm{v}$ genológii, užšie $\mathrm{v}$ teórii epiky, žánru román a v poetológii textu látkou a tematikou iniciované dejinami, užšie históriou exponovaného komponentu (overitel’ná verzus len aktualizovaná udalost', osobnost’ atd?.). A to znamená i to, že si (ne)historické zázemia z minulosti vložené do podtitulu názvu románu Laurus zvolil ruský prozaik a literárny historik vedome a vkladá ho do žánru románu ako širší literárnovedný problém a pre genologický výskum poznávaciu výzvu. Aj na pozadí autorom vedome vytvorenej rozčesnutosti formy a sémantiky vloženej do príčinne zostavenej kompozície, teda aj do funkcie umeleckého textu (vedenie-poznanie; príbeh-odkaz), nazdávame sa, nie pre žánrovú, to by čitatela nenadchlo, ale pre príbeh, ktorý je vnorený do histórie stredovekého Ruska a stredovekého času v živote kontinentu, a to doslova „po celý čas“ autorom do mozaiky organizovanej literárnej reči (dejiny jazyka), dvojakým grafickým záznamom dobovej a súčasnej ruštiny, ale predovšetkým rozprávačským obnovením myslenia a hodnôt stredovekej spoločenskej konvencie pestovanej vo východnom sveta kontinentu. V tom spočíva, a taká je stratégia jedinečnej zovretosti látky a tematiky zo spoločenských a duchovných dejín Starej Rusi. Kompozičná dominancia verifikovatelného a výskumom overeného, objektívne plynúceho času dejín a autorom využitého literárneho času našla svoju podporu na udržanie tak rozsiahleho naračného celku v literárnom priestore, pri náčrtoch z geografie Starej Rusi a v odkazoch na dobovo významné a všeobecné reálie, vedomosti, informácie, no medzi vzdelancami známe dobové lokality s vyspelými etnickými spoločenstvami stredovekého kontinentu, či už ide o vzdelanost', umenie a duchovný stav dobovej Itálie alebo o významom a zložitým jestvovaním odlišných náboženstiev a krest’anov vo vtedajšej Palestíne.

Priama os kompozície voči literárnemu priestoru počíta s dvoma ústrednými bodmi pri putovaní od Florencie po Jeruzalem, ale tie sa utvárajú početnými opismi odbočení na súš či more. Myšlienka pohybu zo zadubenosti po poznanie, zo zabudnutia na výslnie, teda života zloženého z cesty, putovania, hladania, poznávania, úspechu a prehier sa mení v stratégii autora románu Laurus na aktuálnu a univerzálne účinnú výzvu adresovanú rozhladenému čitatelovi. Na náročne zhotovenú umeleckú 
a poznávaciu výzvu pre tých, ktorí príjmu autorov výber látky (Stará Rus), jej torzo zachytené v tematike (príbeh Arsenija) a filozofovanie, rozvinuté v stratégii autora do príbehu textu (hodnoty svetské a duchovné), ale predovšetkým do poznanie dejín ako jestvovanie „ludského“ celku (minulost’ v prítomnosti, prítomnost” v budúcnosti), je rozvinuté do stratégie textu tak, aby sa zretelne oddelilo to, čo je obsiahnuté $\mathrm{v}$ „nehistorickom románe“ do reálneho spoločenského času vzniku románu v miléniu a navodilo výzvu zvažovat' pri jeho typológii verdikt, ako sa dá ujasnit’ význam a hodnota autorom nenáhodne podsunutého paradoxu, ide o tendenciu literárneho príbehu verzus neliterárneho poznania navodeného žánrovým znejasnením „ponuky“ na koexistenciu historického a nehistorického románu. Napokon za súčast' výzvy na zvažovanie o prítomnosti nazeracej koexistencie románu v románe podporia tie vrstvy románu Laurus, ktoré spočívajú $\mathrm{v}$ stroho obnovovanej polarite a súčasne v premene dejinného a spoločenského pohybu v objektívne plynúcom reálnom / literárnom času.

Čas v príbehu vymedzujú termíny stredovek a novovek, numerické informácie rok 7000 a 2019, geografické posuny pri ujasnení si roly javov svet a starodávne Rusko v komentároch, dopovedaniach, poučených výkladoch o javoch či detailoch zo stredoveku i novoveku pre súčasníka, v kompozične a tendenčne obnovovaných ruptúrach medzi kategóriami literárny čas a verifikovatelný historický čas. Čas a na jeho podloží aktualizovaný priestor vymedzili pre román Laurus epicentrum dotyku stratégie autora a stratégie textu: nezanikne to, čo bolo, lebo sa nezmení to, na čo si spoločenstvo vo svojej pamäti a skúsenosti zvyklo, a tak zostáva otázka bez odpovede, kde a kedy sa nájde ten, kto dokázal prekročit’ svoj tieň a čas.

Život pripomína mozaiku a rozpadáva sa na kúsky. mních Innokentij

Kompozíciu textu Laurus vytvorilo - v súlade s kultúrnou tradíciou a praxou stredovekej vzdelanosti - prepojenie štyroch kníh. Reálnu predstavu knihy v románe Laurus predchádzajú písomnosti na vypracovanej brezovej kôre, teda na počiatku Knihy poznania sú brezové zvitky múdreho, starého, chorého, ale nadovšetko zduchovneného liečitela Christofora. Všetko, čo starec vie, to učí Arsenija; autor túto postavu ustanovil za objekt na sledovanie premeny od osirelého vidieckeho nesocializovaného dietat’a po uctievaného liečitela a svätca do jeho poslednej chvíle vo veku starca s ničím a nikým neotrasitelnou krest’anskou mravnou normou. Filozofujúca gnóma o plynulosti a večnosti života spočíva $\mathrm{v}$ prepojení jeho začiatku, stredu a konca. Týmto postupom autor tézu a kompozíciu dostredivo zovrel do stratégie textu a podriadil jej doslova všetko, čo poskytla látka a jej príbehové rozvinutie do univerzálnych paralel medzi plynutím ročných období, zrodom a zánikom ludského života, nevedomost’ou a poznaním, krutost'ou a obetavostou. Vlastne tým, s čím sa 
v Starej Rusi vyrovnával jednotlivec, ked' ho jeho osobné okolnosti dostali do špirály pohybujúcej sa prostredníctvom kladenia otázok a hladania odpovedí, teda do cibrenej individuálnej schopnosti rozpoznat' svoje nadanie a nezištne pomáhat životu (liečitel bylinkár), ale aj umáraniu sa vinou za jeho zmarenie (smrt' Ustiny a narodeného syna), strohým rozlišovaním vztahu $\mathrm{k}$ ludom: biedni a bohatí, krutí a nápomocní, zločinci a zduchovnení, zadubení a fanatici.

V každej zo štyroch kníh sa rozprávačova pozornost' precízne venuje podnetom a následkom všestrannej premeny postavy Arsenija, porozumiet' jemu, znamená porozumiet' histórii, a tak získat' návod na zručnost', ako odlíšit' podstatu, príčinu a hodnotu opustenosti, odcudzenosti a samoty, ale aj zmyslu uloženého do mlčania a sile reči vyjadrenej dopíňaním línie príbehu staroruskými dobovými literárnymi a duchovnými písomnostami, pritom neobíst' popri uchovaných o tie vznikajúce z moderných ruských literárnych slov.

Román Laurus vytvorili časom a postavou prepojené príbehové celky: Kniha poznania (Arsenij a Christofor), Kniha odriekania (Arsejin, po smrti Ustiny sa s ňou identifikuje, predstavuje sa ako dvojjedinec Ustin), Kniha cesty (jurodivý Ustin, jurodivý Floro, taliansky vizionár a spoluputovník Ustina do Jeruzalema s večným svetlom Amrogio Flechia, po jeho vražde nekrest’anom v Palestíne príjme Arsenij meno Ambróz a vráti sa do Ruska), záverečná Kniha pokoja (Arsenij a Innokentij, pustovník, slub mnícha a meno Laurus, Anastasija a jej syn, smrt’ Arsenija).

Stredoveká Rus, ako ju predstavuje román Laurus, obchádza panovnícke rody a systém sociálnej štruktúry spoločnosti stredovekého Ruska. Arsenijov modelový príbeh (jeden výnimočný za všetkých dobových liečitelov, jurodivých, pútnikov, pustovníkov a mníchov) sa rozvinie do navrstvovanej, vždy tenzijnej (dole-hore-dole) sondy zo zábermi do praktického jestvovania, morálky, správania sa a činov, ale zvlášt’ do poverami a bájkami, rozprávkami a mýtmi živeného (ne)vedomia najnižšieho, zadubeného, nevzdelaného, vrchnostou opusteného vidieckeho a malomestského spoločenstva.

V kompozičnom systéme románu Laurus je v poradí tretia kniha vymedzená zmenami priestoru - osada Rukinova rokla, panstvo Belozersko, mesto Pskov. Kniha cesty ponúkne výpravné rozprávanie o putovaní dobovým svetom, priestorom, po súši aj mori, medzi nevercami a krest’anmi, medzi životom a vraždou, pripomenie nemeckých kupcov v Rusku až po kruté výjavy živočišnych útokov pri presadení dobového chápania mat' majetok, uplatnit’ spravodlivost’ a formovat' mocou kolektívnu morálku. Realitou, hodnotou a želaním sa prirodzene, na pozadí „ničoty“ a beznádeje, stáva mýtus smrti: navodí ju choroba, zločin, povedomie viny a prirodzené doznievanie ludského života $\mathrm{v}$ čase.

Literárny priestor ponúka opis prírody a činností, dotvára ich estetický zážitok prejavený ústrednou literárnou postavou, jeho komorný záznam o rozpätí dobového 
poznanie súčasníkov o sveta na západ od stredovekého Ruska. Rozprávač sa detailným opisom sústredí na postavu mladého Florent’ana so schopnost’ou predpovedat' udalosti, ktoré nastanú v blízkej či vzdialenej budúcnosti, na Ambrogia Flecchia. Mladík získava vedomosti v domovine, ale okolnosti ho zavedú do Ruska, aby udalosti okolo smrti dcéry pskovského zbohatlíka ho vyslali na spoločnú pútnickú cestu s Arsenijom do Jeruzaleme $\mathrm{k}$ večnému svetlu. Pôvodný duchovný zámer cesty pútnikov sa nenaplní, pretne ho Ambrogiova vražda nekrestanom a Aresenijov návrat do Pskova.

Kniha cesty odbočuje od Knihy poznania a Knihy odriekania v súlade so stredovekým konceptom svetský a duchovný v tendenčne ladenom „príbehovom“ románu, naberá na napätí, aktualizuje detailnými a vizionárskym zábermi cestu, putovanie, ohrozenie na živote, predsavzatie, nenaplnenie poslania, prírodné a ludské prekážky, strácanie spoločníkov z vôle morských a prírodných živlov; ide o postupy z náčrtov dobrodružnej výpravnej prózy, ktorá sa nevenuje priestoru, ale subjektu a jeho prijímaniu aj vyrovnávaniu sa $\mathrm{s}$ osudom, človekom a ním vyvolávaným nebezpečím. Postava Arsenija nachádza nové riešenie na osobný život v budúcnosti v návrate do pôvodného bodu, teda tam, odkial sa vydal na zamýšlanú výpravu. Následok rozhodnutia iniciuje znova sa navrstvujúca identita postavy v inej postave Arsenij, Ustin, Ambróz - zahladená, sklamaná, opustená, odcudzená, preto oddaná len svojmu vnútru a hladaniu spôsobu. Postava zvažuje, ako môže a dokáže odčinit' vinu sa smrt' tých, ktorých mená prijal. Arsenija zneistila morálka západného sveta, nelíši sa ničím od moci zločinu a nespravodlivosti, ako sa praktikuje v stredovekom Rusku. Zmena spočíva $\mathrm{v}$ tom, že si z cesty po svete a s uvzatým problémom viny za smrt' blízkych upevní mužská postava predsavzatie, venovat' sa duchovnému a pustovníckemu životu bokom od ludí: „Nebol osamelý, lebo nemal pocit, že ho ludia opustili. Všetkých, ktorých niekedy v živote stretol, vnimal akoby boli pri ňom. Ďalej si ticho žili v jeho duši - či už odišli na druhý svet, alebo boli ešte nažive. Pamätal si všetky ich slová, intonácie a pohyby. ich staré slová plodili nové slová, pôsobili na neskoršie udalosti iba slová samostatného Laura. Život bežal d’alej v celej svojej pestrosti“2. Relatívnost' patrí do stratégie a filozofovania autora, zámer vzdat' sa ludí sa nenaplní, ludia ho vyhladávajú a chcú pomoc liečitela, čo Arsenij nikdy neodmietne, lebo sa neodmieta pomoc blížnemu svojmu.

Zorientovanejšie sú vedomosti literárnej postavy pri uplatnení empírie v osobnej existencii, reči tela, poryvov mysle, pri poznaní sociálnych lokalít, v ktorých nebol a nikdy ich nenavštívi, a predsa vie, aká je vzdialenost’ medzi Pskovom a Moskvou, Kyjevom, Novgorodom. Znova poznávací paradox, tieto lokality na ceste Arsenija a jeho sujetových partnerov do kompozície a kníh nevstupujú a okrem odkazu na ne sa v texte neaktualizujú.

2 VODOLAZKIN, J.: Laurus. Nehistorický román. Bratislava: Petrus, 2019, s. 359. 
Tematizovanie liečitel'stva - podložie vedy na sofistikovanú záchranu ludského života - obsiahla a objasňuje praktické prejavy dobového javu v staroruskej spoločnosti. Popri nej sa prejavuje aj jurodivost', nositelia tohto javu (mrzák od narodenia) sa vo vyspelých kultúrach západu po úspešnej liečbe menili na nositelov a šíritelov jeho humánneho uplatnenia. Po morálnom zdôvodnení prejavov spočívajúcich $\mathrm{v}$ útokoch dobovej spravodlivosti voči besom, ktoré v románe Laurus konajú jurodiví, záleží rozprávačovi na tom, aby si čitatel uvedomil, že aj medzi nimi existovalo kastovníctvo, násilie a moc uplatneného vodcovského princípu. Pôvodný význam jurodivosti spájali starí Gréci s mrzákom od narodenia, v stredovekom Rusku sa za jurodivého človeka označoval jedinec bláznivý, slabomyselný alebo bigotne veriaci, ktorého okolie považovalo za božieho človeka s prorockým darom a malo ho v primeranej úcte, alebo aspoň prejavovalo voči nemu ohladuplné správanie; jurodivost' je známa aj v dalších vyspelých dobových kultúrach a náboženstvách ${ }^{3}$.

Nesmút Laure, lebo zatvorený v čase zostaneš už len krátko. mních Innokentij

Tenzijné miesto vytvorí v Arsenijovom príbehu sledovanie osudových premien a skúšok jeho telesného života na život duchovný; tento svet $\mathrm{v}$ stredovekom Rusku patrí vo svojej úplnosti a uplatnení sa do moci a rešpektu spoločenstva duchovných služobníkov v kláštoroch. Tí svojimi víziami, radami, proroctvami a rituálmi praktikovania viery si vynucujú pokoru, dôveru a služby, ovládajú chod staroruskej spoločnosti. Autor s mocou a rešpektom voči kláštorom spája zvest’ o zániku sveta v roku $7000^{4}$. Od počiatku príbehu osamelého chlapca sa všetko vôkol neho spája s nekončiacou morovou epidémiou a ňou vyvolanou vzt’ahovou krízou, okolo ktorej sa sústredí Arsenijov život a udalosti stredovekého Ruska. A tie sú vysvetlované duchovenstvom tak, ako o nej hovorí florentský kupec, „, roku 1492 na Rusi očakávajú koniec sveta"5.

3 Bláznovstvo pre Krista, nie raz aj nástroj jednotlivca, ako upozornit’ na problémy jednotlivca alebo spoločnosti je známe predovšetkým z Ruska, jav jurodivost’ a prejavy jurodivosti poznali starí Gréci, Byzantínci, západné krest’anstvo, pripomínajú ho aj dalšie náboženstvá.

4 Autor intenzívne a gradujúco, dokonca vo vzt’ahu k vzniku a ukončeniu života postavy Arsenija, kompozične pracuje ako s poznávacou pointou románu Laurus s číselnými údajmi rokov ako s odkazmi toho, čo sa stane v nich, či s nimi v dalekej budúcnosti; predpokladáme, že ide o hodnotové a mravné poznávacie podložie (nehistorického románu) literárneho textu, ked formou literárnej veštby jurodivých oslovuje svojich súčasníkov, z pamäti dejín spoločnosti sa nič nestratí, hoci sa to $\mathrm{z}$ jej praktického života na prvý pohlad vytratí. Nazdávame sa, ide o intelektuálne, poučené a premyslené autorovo memento mori venované súčasnosti. Iné či inak zakomponované počítanie letopočtov autor neaktualizoval, uvádza rok narodenia Krista, roky námorných objavov, kultúrne či konkrétne umelecké reálie a dalšie, faktami verifikovatelné reálie z dejín ludstva.

5 VODOLAZKIN, J.: Laurus. Nehistorický román. Bratislava: Petrus, 2019, s. 205. 
Hra s číslami, ktorú prekryjú udalosti zachytené v tretej Knihe cesty a štvrtej Knihe pokoja sa zmení na dva na sebe nezávislé informačné a vedomostné prúdy, ktoré organizuje rozprávač. Prvý prúd kompozične opúšta príčinnú líniu premien Arsenijovho literárneho života, odkazuje verifikovatelnými faktami a rokmi na vojny, katastrofy, objavy kontinentov, na námorné výpravy smerujúce do Ameriky, pokračuje menami a činmi odvíjanými od významu a účinku dalších objavitelov, ale aj na udalosti, ktoré sa stali v storočiach, ktoré nastali podstatne neskôr, teda prežili systémy aj príbehy rozprávané o živote v stredovekom Rusku a priamo sa nedotýkajú histórie ani dejín tejto krajiny. Druhý prúd sa sústredil na príbeh Arsenija, odohráva sa v stredovekom Rusku tak, že sa pod vplyvom okolností mení jeho typová a ludská podstata, čím ho z konkrétneho a osobného príbehu literárnej postavy postupne presúva do schémy historického človeka, teda do všeobecného a mechanicky tradovaného vzorca predka. V jeho literárnej spoločnosti očakávanie konca sveta vrcholí v poučenom (vy)riešení zmyslu tajomnej hry s číslami, hry s osudom a veštbami, paradoxne, s dalšou, inak a inou hyperbolou zostavenou z iného čísla: „Osemnásteho augusta roku 7028 od Stvorenia sveta a roku 1520 od Kristovho narodenia, ked' počet návštevníkov dosahuje stoosemdesiattritisíc, Laurovo telo dvíhajú zo zeme a opatrne ho nesú cez les. Prenášanie sprevádza pohrebný spev vtákov. Zomrelého telo je lahké. Stoosemdesiattritisíc návštevníkov čaká na okraji lesa“6.

Laurus je dobré meno, lebo rastlina, ktorá ti je oddnes menom, je liečivá7. mních Innokentij

Autorský rozprávač sa neubráni profesii svojho tvorcu, či už ide o literárnu históriu, starovekú a stredovekú literárnu a folklórnu kultúru, odkazy na spisovatel’ské (Joyce) či vedecké (Einstein) osobnosti, ktoré so stredovekom nesúvisia, čím vstupuje do logiky a následnosti Arsenijovho príbehu nečakane, prekvapujúco, ale vždy poučene rozprávač vysvetluje jeho odkazy, aby v zátvorke dopovedal, čo so stredovekou reáliou - predbiehajúc, či vracajú sa $\mathrm{v}$ reálnom spoločenskom a dejinnom čase súvisí. Postup je taký, že rozprávač, lebo on to vie, „predbehne“ v čase sekvenciu, ktorá je venovaná postave, alebo čitatel’a orientuje, ba až učí historické reálie, čím sa rozprávačove vstupy dotýkajú odborných vedomostí hlbšieho poznania stredoveku a spôsobu jeho spoločenského organizovania, chápania, hodnotenia života, čo vyjadrí rozprávač i takto: „Ambrózove rukopisy sú v súčasnosti uložené v Kirillo-belozerskej zbierke Ruskej národnej knižnice (Petrohrad). Bádatelia, ktorí ich skúmajú, sa zhodujú na tom, že pisár mal pevnú ruku a zaoblené písmo. Svedčí to podla nich o Ambrózovej

6 Tamže, s. 385 .

7 Tamže, s. 353. 
duchovnej sile a vnútornej harmónii. Vysoký horný dotah (grafémy) písma mäkký jer prezrádza, že $v$ tom čase už definitívne odišiel z kuchyne a o otázky telesnej pohody sa zaujímal vo velmi malej miere"8.

Kategória literárneho času sa tak dostáva do napätia s rozprávačom verifikačne neohraničeným reálnym dejinným časom, čo je nielen zámer, ale aj prvok vplývajúci na žánrový pôdorys textu Laurus. Dejinnú symboliku vnáša do textu aj pomenovanie protagonistu vo vrcholiacej časti jeho duchovne premyslene organizovaného životného príbehu premeny z mladého chlapca na uctievaného liečitela - starca s odovzdaným duchovným životom viere; napokon aj preto dostane v závere vzácnu odmenu v mene Laurus. Naisto sa tak stane preto, lebo autor premýšlal o hodnote a dosahu symbolu vloženého do starorímskeho venca pre vítazov, vavrín pravý má liečivú silu?

... udalosti neprebiehajú vždy v čase. Niekedy prebiehajú len tak, samy od seba. Vyñaté z času ${ }^{10}$. liečitel Arsenij

Autor určil príbehu o minulosti stredovekého Ruska žánrové „povedomie“ zachytené v podtitule jeho názvu (Laurus), opätovne paradoxom - nehistorický román. A tak, ked’ je román nehistorický, teda je to historický román? Či ako je to s jeho žánrom? Historiografia má metodologickú sústavu na vymedzenie toho, čo považuje za historické a nehistorické, za relevantne historický artefakt a za fakt. Literárna veda sa pohybuje genologickou podstatou svojho systému a terminologicky pri textoch, v ktorých sa strategický dôraz kladie na význam a príbehovú invenciu témy, na overitelné fakty, čísla, javy, udalosti a osobnosti taký dôraz, aby odlíšila historický od historizujúceho a nehistorického prozaického žánru. Znova precízne odlišuje historicky verifikovatelný fakt, ktorý sa mení na látku, alebo ho tematizuje, čím zhodnocuje spôsob jeho získania a zapojenia do žánrovej schémy románu a do vymedzenie výberu, do zapojenia a prerozprávania alebo invenčného beletrizovania materiálu prostredníctvom rozprávačských postupov, ktoré v texte Laurus o Arsenijovi aktualizoval ruský prozaik.

Pohyb textu/príbehu medzi realistickým/reálnym a artistným sprevádza i tento výklad: „Zapojení literárního díla do pragmatických souvislostí se jen zdánlivě podobá konzervativnímu vyhledávaní prototypu a mimoliterárních „vzorü“: tam šlo jednosměrný pohyb od reality $k$ dílu, zatímco tu jde o zapojování dynamismu, $z$ něhož vzniká, ale

8 Tamže, s. 343 .

9 Laurus nobilis - bobkový list, vavrín pravý, vavrín lekársky s tvrdými kožovitými listami kopijovitého až ovalného tvaru a viacfarebne kvitnúcimi kvetmi, trpkou až horkou chutou.

10 VODOLAZKIN, J.: Laurus. Nehistorický román. Bratislava: Petrus, 2019, s. 184. 
které také pomáhá vytvářet"11. Nazdávame sa, že žánrové uchopenie textu Laurus smeruje k románu s hybridným komponovaním odborného a literárneho (pôvodného) zdroja, informačného podložia a autorov zámer nespočíva v rekonštrukcii dejín alebo časti z dávnej minulosti, ale v autorovom filozofovaní o existencii, o formách bytia, o obsahu a hodnote, o užitočnosti a zmysle živote jednotlivca a o zmysle, či potrebe a význame minulosti sebazáchovne voči ludskosti a poznaniu presakujúcej do dejov prítomnosti.

Laurus je nehistoricý román len $\mathrm{v}$ tých a $\mathrm{v}$ takých súvislostiach, ked’ autora primárne nezaujímal dejepis z uchovaných análov o stredovekom Rusku a rozhodol sa pre v najširších zdôvodneniach - o spoločenský román predovšetkým tým, že obnovuje príbehom poznanie kontinuity $\mathrm{v}$ ludských dejinách utváraných z činov, presvedčenia a odvahy prekračovat' vôlou, vzdelaním, odvahou, mravným imperatívom prežívajúce spoločenské konvencie, kým sa len dá, dôsledne a v súlade s humanitou zapojenou do podstaty dejov, činov a postojov spojených s človekom a spoločnostou.

\section{Literatúra:}

BÍLIK, R.: Historický žáner v slovenskej próze. Bratislava: Kalligram - Ústav slovenskej literatúry SAV, 2008. ISBN 978-80-8101-137-5.

ČERVENKA, M. a kol.: Na cestě ke smyslu. Poetika díla zo. století. Praha: Torst, 2005. ISBN 80-7215-244-0.

DOHNAL, J.: Proměny modelu světa v ruské próze na přelomu XIX. a XX. století. Brno: Masarykova univerzita, 2012. ISBN 978-80-210-5943-6.

Historický román. [online]. [cit. 4. 10. 2020]. <https://sk.wikipedia.org./wiki/ Historický_román>.

HRABÁK, J.: Úvahy o literatuře. Praha: Československý spisovatel, 1983.

HVIŠČ, J:: Problémy literárne genológie. Bratislava: Veda 1975.

HODROVÁ, D.: Hledání románu. Kapitoly $z$ histórie a typológie žánru. Praha: Československý spisovatel, 1989.

LUKÁCS, G.: Historická próza. Bratislava: Tatran 1976.

PEŠKOVÁ, J.: Role vědomí v dějinách a jiné eseje. Praha: Nakladatelství Lidové noviny, 1997. ISBN 80-7106-217-0.

POSPÍŠIL, I.: Rozpětí žánru. Brno: Sprint-Print, 1992.

11 POSPÍŠIL, I.: Rozpětí žánru. Brno: Sprint-Print, 1992, s. 7. 
POSPÍŠIL, I.: Fenomén šílenství v ruské literatuře 19. a 2o. století. Brno: Masarykova univerzity, 1995. ISBN 80-10-1083-5.

POSPÍŠIL, I.: K teorii ruské literatury a jejím souvislostem. Brno: Masarykova univerzita, 2013. ISBN 978-80-210-6216-0.

Vavrín pravý. [online]. [cit. 4. 10. 2020]. <https://sk.wikipedia.org./wiki/Vavrín_pravý>. VODOLAZKIN, J.: Laurus. Nehistorický román. Bratislava: Petrus, 2019. ISBN 978-80- 89913-14-5.

ŽEMBEROVÁ, V.: Z morfológie prózy. Prešov: Filozofická fakulta Prešovskej univerzity, 2012. ISBN 978-80-555-0510-7.

\section{About the author \\ Viera Žemberová \\ University of Prešov, Faculty of Arts, Department of Slovak Literature and Literary Studies, Prešov, Slovakia \\ viera.zemberova@unipo.sk}


